\title{
Innovation and valorization in supply chain network
}

Luigi Cembalo

Correspondence: cembalo@unina.it Department of Agriculture, AgEcon and Policy Group, University of Naples Federico II, Via Università, 96 80055 Portici - Napoli, Italy

\section{Springer}

\begin{abstract}
Organizations, institutions and new governance mechanisms are taking place in the domain of innovation and valorization of the agrifood sector. Though not new in the literature, this topic is capturing the interest of scholars. It refers to the analysis of new organizations and governance frameworks in the agribusiness. Since this subject needs a deeper analysis, a platform of scientific-based discussion has been built, namely through the eleventh conference of the Wageningen International Conference on Chain and Network Management (WICaNeM) that was held in Capri (Italy) in June 2014 thanks to joining forces of three universities: Wageningen (NL), Bonn (DE) and Naples Federico II (ITA). WICaNeM is a well-known conference concerning management, economics, innovation, valorization and organization of chains and networks in a Life Sciences context. Thanks to Agricultural and Food Economics journal the 2014 conference benefits of a special issue where a selection of five papers were selected. In this short paper a brief presentation of those papers is provided.
\end{abstract}

Keywords: WICaNeM; Governance mechanism; Agribusiness

In the last two decades agrifood sector has been facing new challenges due to many changes occurred in social and political domains: food safety concerns, policy reforms, social and economic turbulences, often resulting in price volatility, just to cite some. As a reaction of these challenges players of the agrifood sector have been re-orienting their business throughout a re-thinking of their relationships within supply chains. Furthermore, rural communities have been re-organizing themselves in an attempt to create value developing a system of alternative food communities (Migliore et al. 2014). New governance structures, organizations and institutions are emerging aiming at innovation and valorization of the agrifood sector. This phenomenon is still under construction and it is capturing the interest of scholars. However, there still is a need for more in-depth investigations either from a theoretical point of view, case study based approaches, and innovative research methodologies.

These topics are not new in the literature. They refer to the analysis of new organizations and governance frameworks in the agribusiness. Williamson (2003, p. 23) and Masten (2000) pointed out that the agrifood sector traditionally provides a sound example of puzzling phenomena able to challenge mainstream theory. With the objective to go into such governance structures, a broader and deeper analysis is needed leading to new theoretical and methodological achievements as well as provide a rich and largely unexplored area for application and refinement of theories (Masten 2000). 
Examples in this domain are the increasing number of consumer-producer networks: Solidarity Purchase Groups, Maintien d'une Agriculture Paysanne, Farmers Markets, and Community Supported Agriculture (Migliore et al. 2015; Cembalo et al. 2013). All these are strategies to re-organize supply chains, mainly at local level, rely on issues such as trust, fairness and social capital (Toler et al. 2009; Pascucci 2010). At a global level, on the other side, new forms of vertical coordination, partnerships and alliances are emerging among heterogeneous stakeholders. Such partnerships increasingly involve, at different levels of the supply chain, NGOs, universities, government agencies, international organizations, agrifood companies, and investors in the attempt to share information and specific assets and to realize common investments (Dentoni and Peterson 2011).

Over the last two decades, a platform of scientific-based discussion has been built. In June 2014 the eleventh conference of the Wageningen International Conference on Chain and Network Management (WICaNeM) was held in Capri (Italy) joining forces of three universities: Wageningen (NL), Bonn (DE) and Naples Federico II (ITA). WICaNeM has become a well-known conference regarding the management, economics, innovation, valorization and organization of chains and networks in a Life Sciences context. The conference also enhances discussions focused on building an agenda from an academic and research perspective, as well as from a company and business one. Put differently, WICaNeM provides the opportunity for attendees to meet large international companies and innovative SME providing vast opportunities to companies wanting to develop their business on an international platform, as well as researchers who want to prepare EU-programs.

Thanks to Agricultural and Food Economics journal the 2014 WICaNeM benefits of a special issue where a selection of value papers, among the best ones presented, were selected. After a peer review process, five papers were accepted for publication with a common research outline concerning innovation and valorization of the supply chain network.

\section{Report}

In "Case study analysis on supplier commitment to added value agri-food supply chains in New Zealand", authors Nic J Lees and Peter Nuthall focus on what attracts suppliers to be committed to long-term relationships in New Zealand agri-food supply chains where suppliers are required to consistently deliver to high product specifications. With a case study based approach authors look at factors determining enduring supply chain relationships. One of the most interesting result is that suppliers are attracted by the supply chain under study due to external economic conditions such as price uncertainty. Moreover, suppliers benefit of a premium price and relationship quality.

A second team of researchers explores a radical innovation in the food and feed industry. Their article "The perfect storm of business venturing? The case of entomology-based venture creation", authors Stefano Pascucci, Domenico Dentoni and Dimitrios Mitsopoulos, takes the reader to the issue of how to create a profit making entomology-based company. Authors first discuss a new venture creation in the agrifood sector. They then analyze the challenges of doing that in presence of a radical innovation. Implementing a venture creation game experiment authors highlight challenges and opportunities of such a business underlying the crucial role of trust and cooperation. 
Moving geographically and in perspective, Marilia B Bossle, Marcia D de Barcellos and Luciana M Vieira analyze the production and consumption of eco-innovation food in Brazil. In "Eco-innovative Food in Brazil: Perceptions from producers and consumers", authors focus on both supply and demand sides in depth to see companies' motivation to adopt eco-innovation strategies, and consumers' perception. Results add empirical evidence on how values and general attitudes influence behavior towards eco-innovative food in the Brazilian food consumption context.

In "Who likes it sparkling? An empirical analysis of Prosecco consumers' profile", authors Laura Onofri, Vasco Boatto and Andrea Dal Bianco shift on the concept of certification of quality in a specific Region of Italy where Prosecco wine is produced. This wine can be certified as Controlled Denomination of Origin (CDO) and Controlled and Guaranteed Denomination of Origin (CGDO). The two certifications require different effort due to diverse quality standards, being CGDO stricter than CDO. However, most consumers seem not to make any difference between the two. For that reason authors made a study to elicit the preferences of consumers buying Prosecco in an attempt to understand how to add value to quality certification effort. A probit model was implemented on a large sample of homescan data.

A second team of Italian reasearchers explores the social embeddedness of a specific food community network. In "Alternative food networks as a way to embed mountain agriculture in the urban market: the case of Trentino", authors Emanuele Blasi, Clara Cicatiello, Barbara Pancino and Silvio Franco explore the mechanisms to deliver environmental and recreational value of peri-urban agriculture to the city. The role of traditional agriculture in peri-urban context risks to be replaced by non-agricultural and post-productive activities. So, farms re-organize themselves to move forward a multifunctional approach. One of the multifunctionality is the creation of alternative food network. The analysis is conducted in Trentino, Italy. The main result is the reinforcement of a link between the mountains and the city. Consumers' attitudes toward these practices are already very positive, thanks to their strong territorial identity. Results are in line with many other studies where it is shown the value creation of alternative food networks and their role in terms of social embeddedness.

\section{Conclusions}

Taken together, this collection of articles provides fresh insights into the multifaceted aspects of innovation and valorization of the supply chain network. The works presented here underline growing movements to relocate and revise the control and methods of food production as well as the relevance of sustainable method of production. 
References

Cembalo L, Migliore G, Schifani G (2013) Sustainability and new models of consumption: the solidarity purchasing groups in Sicily. J Agric Environ Ethics 26(1):281-303

Dentoni D, Peterson HC (2011) Multi-stakeholder sustainability alliances: a signalling theory approach. Int Food Agribusiness Manage Rev 14(5):83-108

Masten SE (2000) Transaction-Cost Economics and the Organization of Agricultural Transactions. In: Baye MR (ed) Advances in Applied Microeconomics - Industrial Organization, p 193

Migliore G, Schifani G, Dara Guccione G, Cembalo L (2014) Food community networks as leverage for social embeddedness. J Agric Environ Ethics 27(4):549-567

Migliore G, Schifani G, Cembalo L (2015) Opening the black box of food quality in the short supply chain: effects of conventions of quality on consumer choice. Food Qual Preferences 39(1):141-146

Pascucci S (2010) Governance structure, perception and innovation in credence food transactions: the role of food community networks. Int J Food Syst Dynamics 1(3):224-236

Toler S, Briggeman BC, Lusk JL, Adams DC (2009) Fairness, farmers markets, and local production. Am J Agric Econ 91 (5):1272-1278

Williamson OE (2003). Transaction cost economics and agriculture - An excursion. In Multifunctionality Agriculture: A New Paradigm for European Agriculture and Rural Development. Edited by Huylenbroeck GV, Durant G. Ashgate Pub Ltd. Aldershot, UK

Submit your manuscript to a SpringerOpen ${ }^{\circ}$ journal and benefit from:

- Convenient online submission

- Rigorous peer review

- Immediate publication on acceptance

- Open access: articles freely available online

- High visibility within the field

- Retaining the copyright to your article

Submit your next manuscript at $>$ springeropen.com 